\title{
A SEMI-EMPIRICAL MODEL TO PREDICT DIESEL ENGINE COMBUSTION PARAMETERS
}

\author{
B. Ghobadian, G. Najafi and M. Nayebi \\ Tarbiat Modares University, Tehran, Iran \\ Email: ghobadib@modares.ac.ir
}

\begin{abstract}
To carry out the investigation, a cylinder pressure model was developed based on the position of the crankshaft, engine load, engine speed, and fuel injection time. This model takes into account the maximum number of parameters involved. The accuracy of the model was verified by experimental results. The average error of the cylinder pressure, the average radical of the square of the error of the cylinder pressure, and the average error of maximum pressure were calculated at $1.85 \%, 3.32$, and $0.66 \%$ (of maximum pressure), respectively. This model was compared with the model by Conolly and Yagle; the two models are similar in terms of the pressure relating the square of time and the exponential of time. This model appears applicable to other diesel engines. The results of the equation and experimental results were compared and described by a Fourier series, which is indicative of the cylinder pressure level between them.
\end{abstract}

Keywords: cylinder pressure model; parameters of engine; diesel engine.

\section{INTRODUCTION}

Analysis of data of cylinder pressure versus crank angle over the compression and expansion strokes of an engine's operating cycle, can be used to obtain quantitative information on the progress of combustion and on the release of the chemical energy of fuel (Nematizade, Ghobadian, \& Najafi, 2012). Quantitative information on the progress of the combustion process can also be obtained from an examination of the time history of heat release. Parameters related to the development of cylinder pressure are some of the most important combustion parameters that influence overall engine noise and combustion components (Kiani, Ghobadian, Tavakoli, Nikbakht, \& Najafi, 2010; Azad, Ameer Uddin, \& Alam, 2012). These parameters are peak cylinder pressure, maximum rate of cylinder pressure rise, and the maximum acceleration of cylinder pressure. Analyses of engine cylinder pressure data have led to a widely accepted descriptive model of the comparison-ignition engine combustion process. For example, heat release can be calculated from cylinder pressure versus crank angle data. The design of an internal combustion (IC) engine will recognize the tremendous advantage of a general model for analyzing in-cylinder pressure. Connolly and Yagle (1993) presented a new model relating cylinder combustion pressure to crankshaft angular velocity in an IC engine. There are three aspects to this model. First, by changing the independent variable from time to crankshaft angle, a non-linear differential equation model becomes a linear first-order differential equation. Second, a new stochastic model for combustion pressure uses the sum of a deterministic waveform and a raised cosine window, amplitude-modulated by a Bernoulli-Gaussian random sequence, parametrizing the pressure by the sample modulating sequence (Abbaszaadeh et al., 2012). This results in a state equation for the square of angular velocity sampled at 
every combustion, using the modulating sequence as input. Third, the inverse problem of reconstructing pressure from noisy angular velocity measurements can be formulated as a state-space disconsolation problem, which can be solved using a Kalman-filterbased disconsolation algorithm. Simulation results show that the parameterized pressure can be deconvolved at low noise levels and combustion misfires detected, all in real time (Aggarwal, 1995) An accurate model of specific heat ratio is important for an accurate heat release analysis, because the specific heat ratio couples the energy of the system to other thermodynamic quantities (Ghobadian, Rahimi, Nikbakht, Najafi, \& Yusaf, 2009). The objective is to investigate models of the specific heat ratio for singlezone heat release, and to find a model accurate enough to introduce a cylinder pressure modeling to measure cylinder pressure noise (Smit \& Fox, 1955; Amana, 1974). A model was programmed in FORTRAN, which predicts the cylinder pressure throughout the intake, comparison, combustion, expansion, and exhaust processes that comprise the engine operating cycle. Pressure was modeled as a function of the angle of the crank, which ran for 720 degrees per cycle, or two revolutions, because the crank completed two rotations per cycle. The valve, engine geometry, engine speed, and inlet pressure were entered into the model. This model predicted the pressure of the gas in a cylinder by incorporating the isotropic gas process model, and it predicts the pressure in the cylinder fairly accurately (Kopa \& Kimura, 1960; Yee, \& Linville, 1960). The development of a computational fluid dynamics methodology for IC engines represents a particular challenge because of the many complex features and phenomena, perhaps more so than in any other widely used mechanical device. Understanding the process that occurs in the combustion chamber and the correlation between parameters is important to the design and essential for exploring new solutions for reducing costs and improving development efficiency; therefore, a model toinvestigate combustion in diesel engines has been developed (Rahim, Mamat, Taib, \& Abdullah, 2012). Predictions have been compared with extensive data from a production direct injection (DI) diesel engine over a wide range of operating conditions (Heywood, 1988; Ladommatos, Abdelhalim, Zhao, \& Hu, 1996; Aziz, Firmansyah, \& Shahzad, 2010). A new methodology for the analysis of in-cylinder pressure in DI diesel engines was presented. The study of total pressure is shown to be insufficient and the proposed technique is intended to be an alternative and more efficient tool, because it may provide a better understanding of the physical mechanisms. The main idea is to decompose the in-cylinder pressure evolution according to three phenomena that occur during the operation of a diesel engine: pseudo-motored, combustion, and resonance excitation. In order to validate this new method, it is applied to combustion noise analysis. Actually, the combustion process in DI diesel engines may be considered as an important source of noise, and the traditional approach is based mainly on the interpretation of objective overall spectral levels of both in-cylinder pressure and radiated noise obtained from Fourier analysis (Rahimi, Ghobadian, Yusaf, Najafi, \& Khatamifar, 2009). However, this approach has been shown unable to describe all the relevant aspects of the problem, whereas the results obtained from the proposed decomposition technique, exhibit a fair qualitative correlation between in-cylinder pressure and combustion noise issues. Further development of this approach could provide a useful tool for the development of optimal injection strategies, fulfilling not only performance considerations, but also sound quality requirements for combustion noise in DI diesel engines (Heywood, 1988). The objective of this study is to model the cylinder pressure of a diesel engine. The theoretical method will be compared with experimental results. 


\section{EXPERIMENTAL SETUP}

For a comprehensive investigation and the appointment of a model for diesel combustion pressure, parameters that cause a change of pressure must be detected. These parameters are: $N$ - engine speed (rpm), $L$ - engine load torque ( $\%$ of the rated value), $M_{f}$ - amount of fuel, $T$ - time, and $P$ - pressure. Thus, we have $P=f\left(N, L, M_{f}, T\right)$. In order to derive this model, we need to measure these five parameters. An existing 7.1 $\times 7.1 \mathrm{~m}$ room, having a volume of $183 \mathrm{~m}^{3}$, served as the control laboratory for the engine test cell by adding adequate accessories. A schematic diagram of the general layout and instrumentation is shown in Figure 1. Figure 2 shows a photograph of the engine test cell. A single cylinder $3.68 \mathrm{~kW}, 1500 \mathrm{rpm}$, stationary DI diesel engine was chosen for experimental investigation, the specifications of which are given in Table 1.
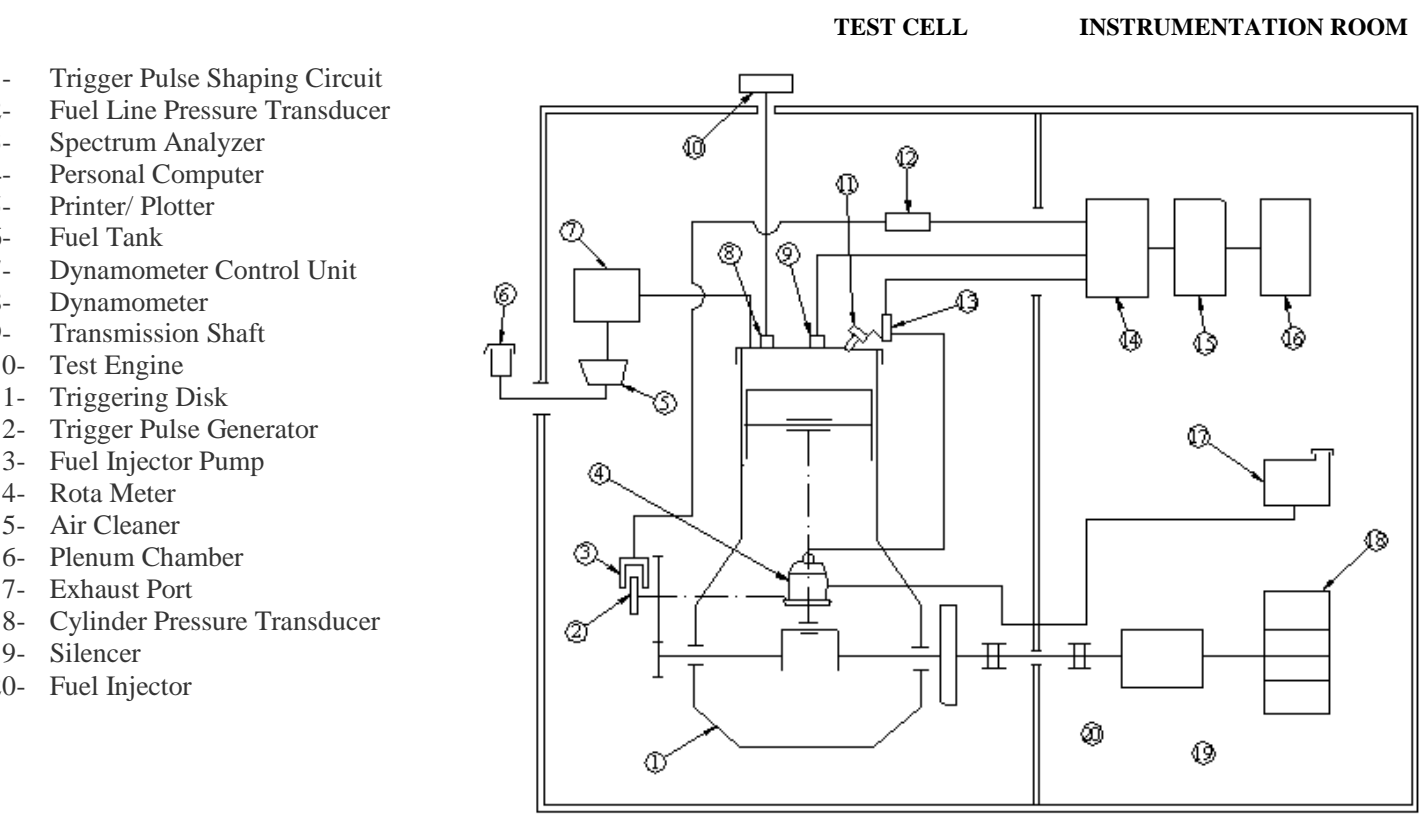

Figure 1. Schematic representation of the experimental setup.

Table 1. Specifications of the test engine.

\begin{tabular}{ll}
\hline Manufacturer & Kirloskar \\
\hline Number of cylinder & One \\
Engine cycle & Four stroke \\
Combustion system & Direct injection \\
Air intake system & Naturally aspirated \\
Cooling system & Water cooled \\
Bore diameter & $80 \mathrm{~mm}$ \\
Stroke length & $110 \mathrm{~mm}$ \\
Displacement & $0.553 \mathrm{liter}$ \\
Compression ratio & $16.5: 1$ \\
Rated engine speed & $1500 \mathrm{rpm}$ \\
Torque at rated speed and load & $23.0 \mathrm{Nm}$ \\
\hline
\end{tabular}




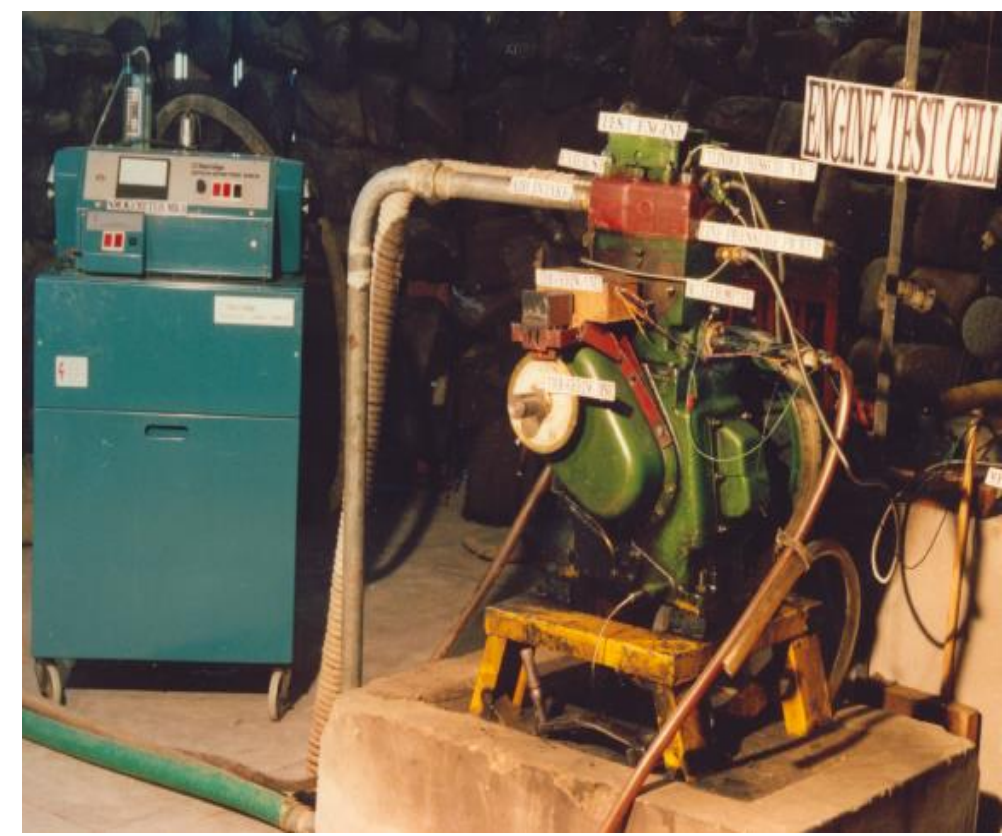

Figure 2. Engine test cell.

In the present experiments, a polystable quartz KI 6121A1 Kistler Piezo-electric Pressure transducer, capable of sustaining steady temperatures up to $350{ }^{\circ} \mathrm{C}$ and flash temperatures of up to $2500{ }^{\circ} \mathrm{C}$, was used. The pressure transducer was flush-mounted in the cylinder head, to avoid any Helmholtz-type resonances, directly above the combustion bowl. In these experiments, a KI 6225 Kistler Piezo-electric quartz pressure transducer with a pressure range 0-2000 bar was used to measure the fuel line pressure and an ECB Benz Eddy Current Dynamometer with its associated modules was used for loading the engine and its control. The matrix of the test conditions is given in Table 2. The levels of each factor is varied in turn while the rest of the factors are held at fixed levels. The selected factors, i.e., the engine operating and injection parameters (variables) selected, are the ones known to have an influence on engine combustion pressure and are given below:

i) Engine speed.

ii) Engine load torque.

iii) Fuel injection timing.

Implementation of this test matrix (Table 2) resulted in 80 test runs, varying one factor at a time.

Table 2. Test matrix

\begin{tabular}{lccccc}
\hline Factors (Parameters) & \multicolumn{5}{c}{ Levels (Steps) } \\
\cline { 2 - 6 } & 1 & 2 & 3 & 4 & 5 \\
\hline Engine speed $(\mathrm{rpm})$ & 1200 & 1350 & 1500 & 1650 & - \\
Engine load torque $(\%$ of the rated value) & 55 & 70 & 85 & 100 & - \\
Fuel injection timing $\left({ }^{\circ} \mathrm{CA}\right.$ btdc) & 22 & 27 & 32 & 37 & 42 \\
\hline
\end{tabular}




\section{RESULTS AND DISCUSSION}

By modeling and measuring the pressure inside the cylinder while the engine is running, very accurate details of the combustion process can be analyzed. Two things are of interest when looking at the graphs of cylinder pressure. One is the peak pressure and the other is the area under the pressure curve; all of the power generated by the engine comes from the area under this pressure curve. As seen in Figure 3, the curve of pressure-crank angle is divided to four zones: 1 - Climbing zone, 2 - Peak of the curve, 3 - Decreasing zone, and 4 - Zone where pressure amounts are less than 5 (bar). These quantities are neglected because these data are not accurate enough. For the climbing and decreasing zones, we can consider linear, logarithmic, polynomial, power, or exponential equations.

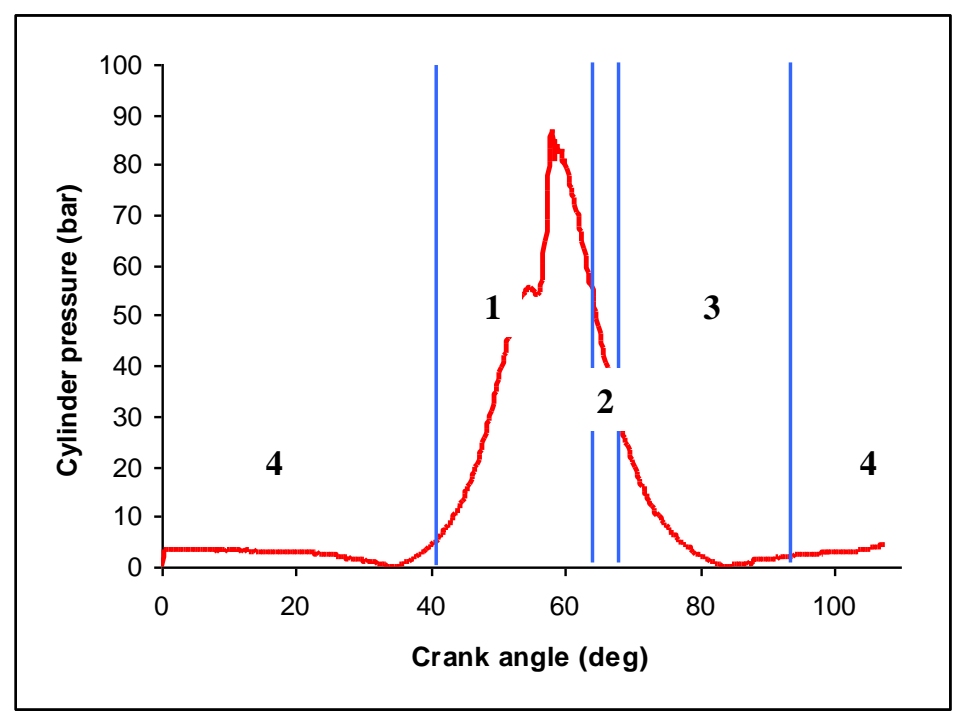

Figure 3. Four zones for the curve of pressure-crank angle diagram.

An exponential equation was selected for describing the climbing zone of curve (1), and a polynomial equation was chosen for the decreasing zone (2), because of simplification of the calculations. Therefore, we will have:

$$
\begin{gathered}
F_{1}(t)=A_{1} e^{B_{1} t} \\
F_{2}(t)=A_{2} t^{2}-B_{2} t+C_{2}
\end{gathered}
$$

Eq. (3) is used to connect the two sections of the curve (Aggarwal, 1995):

$$
P=\left[F_{1}(t)^{-\frac{1}{k}}+F_{2}(t)^{-\frac{1}{k}}\right]^{-k}
$$

$A_{1}, B_{1}, A_{2}, B_{2}, C_{2}$, and $K$ are constants, $P$ is pressure (bar), and $t$ is the crank angle (degree). For every 80 curves, the value of $K$ should be calculated in a way such that the error between the calculation and experiment decreases with regard to this point, and MATLAB software was used for this. Eq. (3) can be written based on engine speed and time (Eq. (4)) and on the load, which is determined in Eq. (5). 


$$
P(N, t)=\left[\left(F_{A} N_{1} e^{F_{B} N_{1} t}\right) \frac{-1}{F_{k}(N)}+\left(F_{A} N_{2} t^{2}-F_{B} N_{2} t+F_{C} N_{2}\right)^{\frac{-1}{F_{k}(N)}}\right]^{-F_{k}(N)}
$$

where $F_{A} N_{i}=A_{i 1} N+A_{i 2} ; F_{B} N_{i}=B_{i 1} N+B_{i 2} ; F_{C} N_{2}=C_{21} N+C_{22} ; F_{k}(N)=K_{1} N+K_{2}$ $i=1,2$, and $N$ is the engine speed (rpm).

$$
P_{A, B, C, K}(N, L)=\left(A_{i 1} L^{2}+A_{i 2} L+A_{i 3}\right) N+\left(A_{i 4} L^{2}+A_{i 5} L+A_{i 6}\right)
$$

where $L$ is the load.

We combine Eqs. (4) and (5) and the final equation for the combustion pressure based on crank angle, engine speed, and engine load is derived, as shown by Eq. (6).

$\mathrm{P}(\mathrm{N}, \mathrm{L}, \mathrm{t})=$

$\left[\left(F_{A}(N, L)_{1} \cdot e^{F_{B}(N, L)_{1} \cdot t}\right)^{-\frac{1}{F_{k}(N, L)}}+\left(F_{A}(N, L)_{2} \cdot t^{2}-F_{B}(N, L)_{2} \cdot t+F_{C}(N, L)_{2}\right)^{-\frac{1}{F_{K}(N, L)}}\right]^{-F_{K}(N, L)}$

The correctness and accuracy of the final equation, Eq. (6), which is a statement for diesel engine combustion pressure, was investigated. As a general rule, there are some statistical formulas that ascertain the integrity of an equation based on error measurement and the dispersion of the theoretical and experimental data (Smit \& Fox, 1955).

Average Error: This error was calculated by using Eq. (7):

$$
E_{1}(P)=\frac{1}{N} \sum_{k=1 \ldots N}\left|P\left(X_{k}-Y_{k}\right)\right|
$$

The quantity of this error was calculated to be about: $\mathrm{E}_{1}(\mathrm{P}(\mathrm{L}, \mathrm{N}, \mathrm{t}))=1.853$ (bar).

Square Root of Average Error: By using Eq. (8) and ErrorSqu.cpp software. this parameter was determined to be about 3.325.

$$
E_{2}(P)=\left[\frac{1}{N} \sum_{k=1 \ldots N}\left(P\left(X_{k}\right)-Y_{k}\right)^{2}\right]^{\frac{1}{2}}
$$

$\mathrm{E}_{2}(\mathrm{P}(\mathrm{L}, \mathrm{N}, \mathrm{t}))=3.325$ (bar).

Maximum of Error: This error was calculated by using Eq. 9 and Errormax.cpp software.

$$
E_{\max }(P)=\max \left(\left|P\left(X_{k}\right)-Y_{k}\right|\right)
$$

$$
\mathrm{E}_{\max }(\mathrm{P}(\mathrm{N}, \mathrm{L}, \mathrm{t}))=13 \text { (bar). }
$$

The diesel combustion process is central to the engine operation and is at the root of the generation of engine noise. Heat released during combustion into the cylinder 
gases governs the cylinder pressure development and therefore, the power output (Najafi, Ghobadian, Tavakoli, Buttsworth, Yusaf, \& Faizollahnejad, 2009). At the same time, this development of cylinder pressure controls the loading of the engine structure and to a large extent, the generation of engine noise, which is merely a consequence of the response of the engine structure to the excitations arising during the cycle. Analysis of the cylinder pressure versus crank angle data over the compression and expansion strokes of the engine operating cycle, can be used to obtain quantitative information on the progress of combustion and on the release of the chemical energy of the fuel (Ghobadian et al., 2009). It has been shown that the noise due to combustion in a diesel engine is determined by the form of the pressure rise. The exact shape of the cylinder pressure diagram and the peak cylinder pressure have been suggested as the parameters controlling engine noise (Pederson \& Qwale, 1974; Lee \& Choi, 1991; Mozafary, 1994; Farrauto \& Voss, 1996; Mogi, Tajima, Hosoya, \& Shimoda, 1999). From the above discussion, it is determined that the peak of cylinder pressure is a very important parameter in the diesel engine combustion process. In this study, the values of engine pressure were measured and calculated by means of the equations presented. The experimentally and theoretically (Eq. (6)) determined values of pressure are compared in Table 3. Data were collected from the diesel engine at different engine speeds $(1350 ; 3-1500 ; 5)$, inject angle $(37 ; \mathrm{T}-32 ; \mathrm{U}-27 ; \mathrm{V})$, loads $(70 ; 3-85 ; 4-100 ; 5)$, and cylinder pressure. The values and variables were entered into the model and the model was then used to predict the pressure in the cylinder. The model was fairly accurate in its predictions of cylinder pressure. Figure 4 presents the actual and model data at 1350 rpm, 37 degrees of inject angle, and different loads $(70,85,100)$. The average deviation of all trials between the model data and the actual data was about $1.5 \%$.

Table 3. Comparison between experimental and theoretical maximum cylinder pressure.

\begin{tabular}{|c|c|c|c|c|c|c|}
\hline \multirow{2}{*}{$\begin{array}{c}\text { Deviation } \\
(\%)\end{array}$} & \multirow[t]{2}{*}{ Difference } & \multicolumn{2}{|c|}{ Engine Pressure (bar) } & \multirow[t]{2}{*}{ Load } & \multirow{2}{*}{$\begin{array}{l}\text { Inject } \\
\text { angle } \\
\text { (deg) }\end{array}$} & \multirow{2}{*}{$\begin{array}{l}\begin{array}{l}\text { Engine } \\
\text { speed }\end{array} \\
\text { (rpm) }\end{array}$} \\
\hline & & Theoretical & Experimental & & & \\
\hline-0.52 & 0.5 & 95 & 95.5 & 70 & 37 & 1350 \\
\hline 0.57 & 0.56 & 97.26 & 96.7 & 85 & & \\
\hline 1.75 & 1.79 & 101.79 & 100 & 100 & & \\
\hline-1.37 & 1.33 & 96.67 & 98 & 70 & & \\
\hline-0.87 & 0.884 & 100.61 & 101.5 & 85 & 32 & \\
\hline 0.76 & 0.794 & 103.79 & 103 & 100 & & \\
\hline 1.15 & 1.056 & 91.056 & 90 & 70 & & \\
\hline 0.65 & 0.626 & 95.626 & 95 & 85 & 27 & \\
\hline-0.17 & 0.171 & 98.229 & 98.4 & 100 & & \\
\hline 0.71 & 0.697 & 97.697 & 97 & 70 & 37 & 1500 \\
\hline 0.78 & 0.773 & 98.473 & 97.7 & 85 & & \\
\hline 0.21 & 0.221 & 101.621 & 101.4 & 100 & & \\
\hline-0.28 & 0.286 & 98.714 & 99 & 70 & & \\
\hline-0.25 & 0.25 & 99.25 & 99.5 & 85 & 32 & \\
\hline 0.25 & 0.26 & 101.96 & 101.7 & 100 & & \\
\hline-1.06 & 0.967 & 90.63 & 91.6 & 70 & & \\
\hline-0.54 & 0.525 & 95.475 & 96 & 85 & 27 & \\
\hline 0.23 & 0.23 & 97.23 & 97 & 100 & & \\
\hline
\end{tabular}




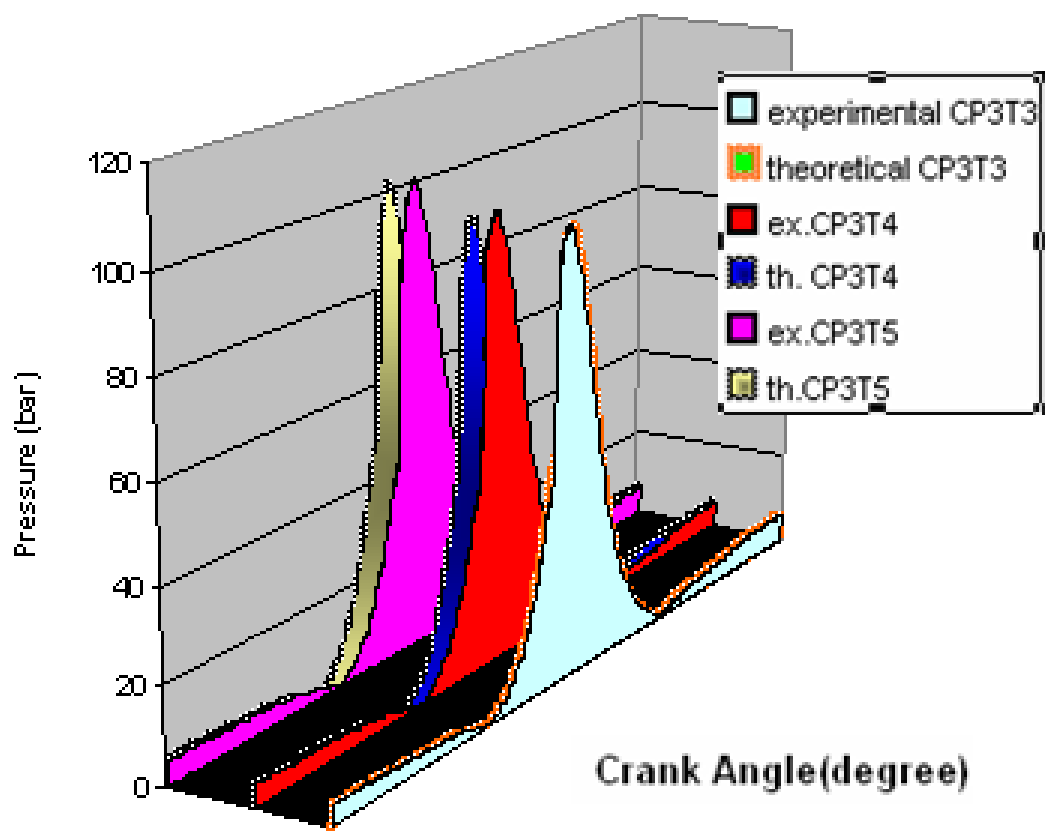

Figure 4. Comparison between experimental and theoretical cylinder pressure values.

In the model of Connolly and Yagle (1993), there are two parameters: pressure and time. In this study, the current model was compared with the model of Connolly and Yagle under the same conditions. Figure 5 presents the comparison between the model of the present study with that of Connolly and Yagle. It can be seen that the maximum error between the results of Connolly and Yagle and the current model is about $1.1 \%$. As the cylinder pressure development is a recurrent phenomenon, it could also be described fully by a Fourier series, such that the characteristics of the exciting forces could be examined in both time and frequency domains. Therefore, the narrow band cylinder pressure level (CPL) spectra have long been used as a measure of the exciting propensities of cylinder pressure. Using the CPL curve is one way to compare the theoretical and experimental results. By using FFT.cpp, the CPL was calculated and the results of the experimental data and theoretical values were compared (Figure 6).

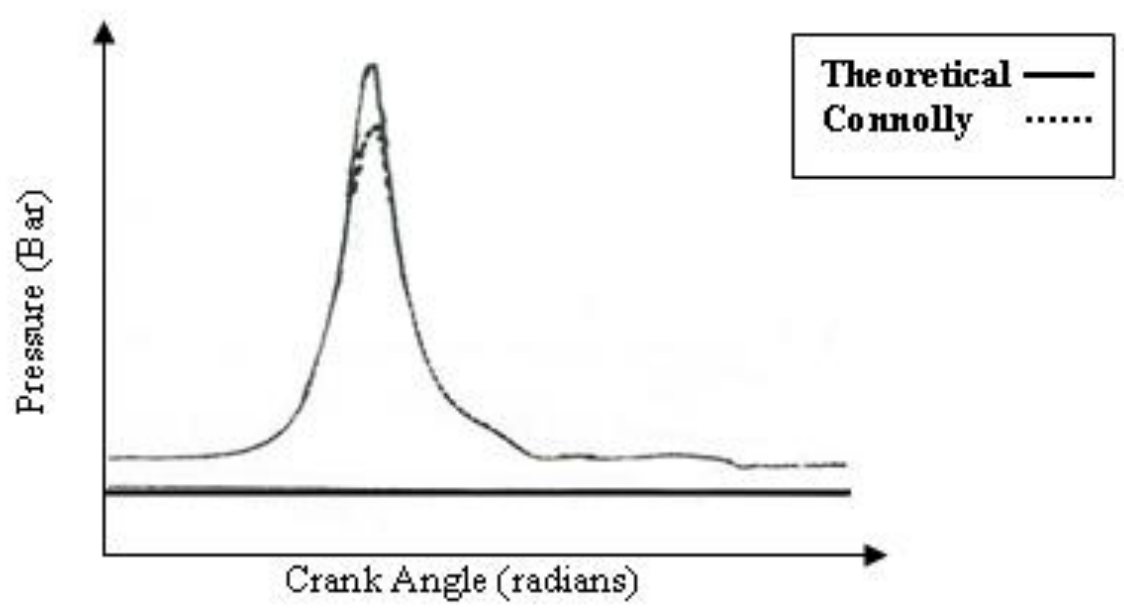

Figure 5. Comparison between Connolly and results of proposed model. 


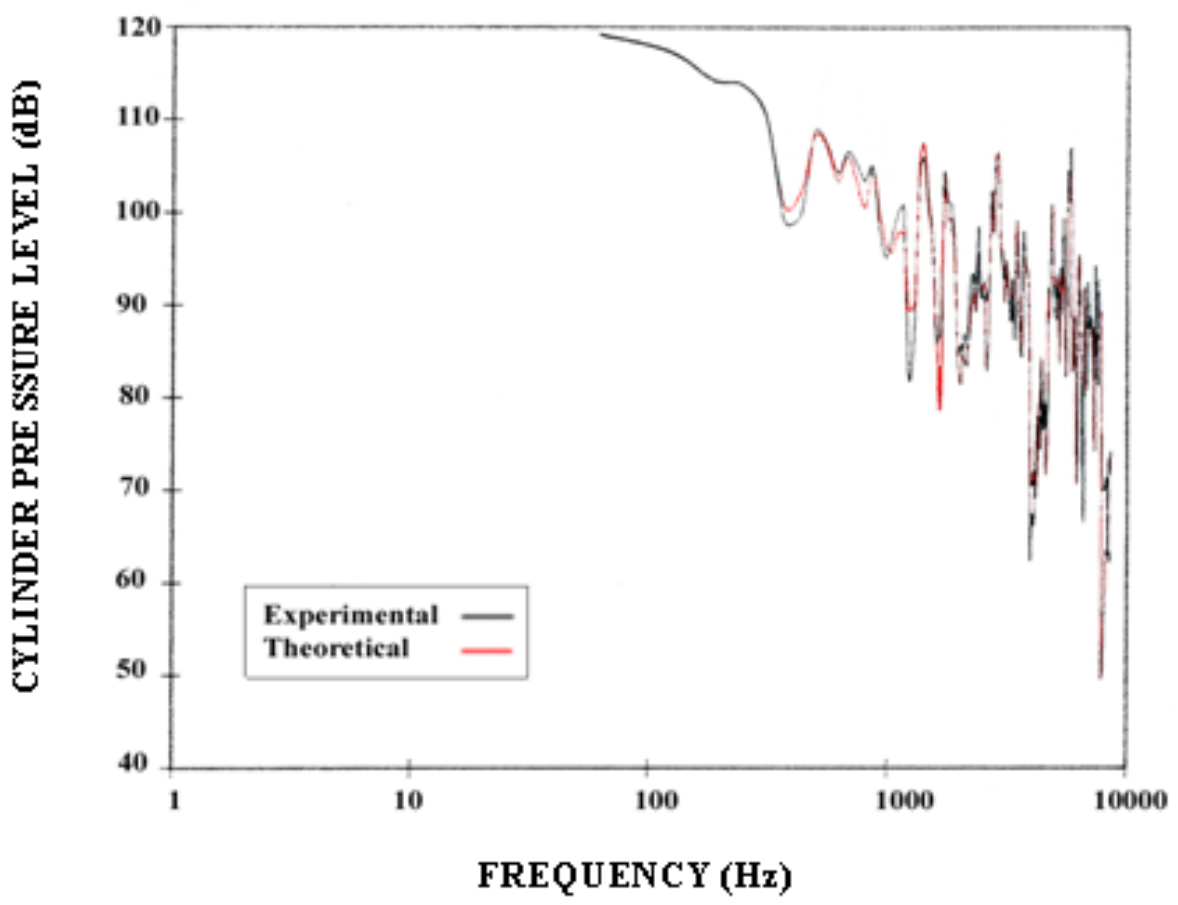

Figure 6. Comparison between experimental data and theoretical values for CPL (full load, inject angle 42 degrees, and engine speed $1200 \mathrm{rpm}$ )

\section{CONCLUSIONS}

Diesel combustion processes are very complex and their detailed mechanisms are not well understood. The study of emissions and fuel economy of a diesel engine requires a basic understanding of the processes of mixture formation, ignition delay, cylinder pressure, and combustion and emission formation, as they occur in the diesel engine combustion chamber. Fundamental equations that model and express the basic processes of diesel cylinder pressure were discussed in this paper. Experimental and theoretical results were compared. The accuracy of the model was proven by comparing the test results. The average error of the cylinder pressure, the average radical of the square of the error of the cylinder pressure, and the average error of maximum pressure were calculated as $1.85 \%, 3.32,0.66$ (percent of maximum pressure), respectively, in which all the figures are accurate.

\section{REFRENCES}

Abbaszaadeh, A., Ghobadian, B., Omidkhah, M. R., \& Najafi, G. (2012). Current biodiesel production technologies: A comparative review. Energy Conversion and Management, 63, 138-148.

Aggarwal, K. M. (1995). Automobile design program. Delhi: Satya publisher.

Amana, C. A. (1974). Why the piston engine lives on. Machine Design, 46, 1-5.

Azad, A. K., Ameer Uddin, S. M., \& Alam, M. M. (2012). A comprehensive study of DI diesel engine performance with vegetable oil: an alternative boi-fuel source of energy. International Journal of Automotive and Mechanical Engineering, 5, 576-586. 
Aziz, A. R. A., Firmansyah, \& Shahzad, R. (2010). Combustion analysis of a CNG direct injection spark ignition engine. International Journal of Automotive and Mechanical Engineering, 2, 156-170.

Connoly, F. T., \& Yaggle, A. E. (1993). Modeling and identification of the combustion pressure process in internal combustion engines. Journal of Engineering for Gas Turbines. 115, 65-75.

Farrauto, R. J., \& Voss, K. E. (1996). Monolithic Diesel oxidation catalysts. Applied Catalysis B: Environmental, 10, 29-51.

Ghobadian, B., Rahimi, H., Nikbakht, A. M., Najafi, G., \& Yusaf, T. F. (2009). Diesel engine performance and exhaust emission analysis using waste cooking biodiesel fuel with an artificial neural network. Renewable Energy, 34, 976-982.

Heywood, J. B. (1988). Internal combustion engine fundamentals. New York: McGrawHill.

Kiani Deh Kiani, M., Ghobadian, B., Tavakoli, T., Nikbakht, A. M., \& Najafi, G. (2010). Application of artificial neural networks for the prediction of performance. Energy, 35, 65-69.

Kopa, R. D., \& Kimura, H. (1960). Exhaust gas recirculation as a method of nitrogen oxides control in an internal combustion engine. APCA 53rd Annual Meeting, Cincinnati, Ohio, USA.

Ladommatos, N., Abdelhalim, S. M., Zhao, H., \& Hu, Z. (1996). The dilution, chemical, and thermal effects of exhaust gas recirculation on diesel engine emissions. SAE Paper No. 961165.

Lee, C. S., \& Choi, N. J. (1991). A study on the variations of combustion characteristics in diesel engine. SAE Paper No. 911245.

Mogi, H., Tajima, K., Hosoya, M., \& Shimoda, M. (1999). The reduction of diesel engine emission by using the oxidation catalysts on Japan Diesel 13 mode cycle. SAE Paper No. 1999-01-047.

Mozafary, A. (1994). Exhaust gas recirculation in spark ignition engine. Advanced Heat Transfer ASME, 64(1), 197-202.

Najafi, G., Ghobadian, B., Tavakoli, T., Buttsworth, D. R., Yusaf, T. F., \& Faizollahnejad, M. (2009). Performance and exhaust emissions of a gasoline engine with ethanol blended gasoline fuels using artificial neural network. Applied Energy, 86, 630-639.

Nematizade, P., Ghobadian, B., \& Najafi, G. (2012). Investigation of fossile fuel and liquid biofuel blend properties using arteficial neural network. International Journal of Automotive and Mechanical Engineering, 5, 639-647.

Pedersen, P.S., \& Qwale, B. (1974). A model for the physical part of the ignition delay in a diesel engine. SAE Paper No. 740716.

Rahim, R., Mamat, R., Taib, M. Y., \& Abdullah, A. A. (2012). Influence of fuel temperature on a diesel engine performance operating with biodiesel blended. Journal of Mechanical Engineering and Sciences, 2, 226.236.

Rahimi, H. Ghobadian, B., Yusaf, T., Najafi, G., \& Khatamifar, M. (2009). Diesterol: An environment-friendly IC engine fuel. Renewable Energy, 34, 335-342.

Smit, H., \& Fox, M. M. (1955(. Automobile exhaust and ozone formation. SAE Golden Anniversary Meeting, Detroid, Michigan, USA.

Yee, S. Y., \& Linville, W. (1960). The effect of exhaust gas recirculation on oxides of nitrogen. APCA 53rd Annual Meeting, Cincinnati, Ohio, USA. 